\title{
Differentiation and conservation status of wet meadows of the Calthion palustris alliance in areas covered by the agri-environmental scheme
}

\author{
Aleksandra Kazuń", Filip Jarzombkowski, Ewa Gutowska, Dorota Kotowska, \\ Katarzyna Kotowska, Magdalena Kowalska, Lukasz Krajewski, Anna Szczepaniuk, \\ Katarzyna Topolska, Hubert Piórkowski
}

Institute of Technology and Life Sciences, Falenty, al. Hrabska 3, 05-090 Raszyn, Poland, *e-mail: olakazun@op.pl

\begin{abstract}
The research subject is the differentiation of plant communities and the preservation status of wet meadows of the Calthion palustris alliance at sites included in subsidy packages 4 and 5 of the agri-environmental scheme. The habitat was studied on 697 agri-environmental plots located in different areas of Poland. The obtained results show high differentiation of the plant communities, which could be considered as representative of the Calthion palustris alliance meadows in Poland. Disturbances in the habitat conditions were observed on most of the plots and they included: disappearance of characteristic species of the Calthion palustris alliance, encroachment of native, expansive species as well as desiccation of the habitat and the associated eutrophication, caused mostly by unidirectional land drainage systems. The study also attempted to determine the conservation prospects of the habitat considering measures implemented under the agri-environmental scheme.
\end{abstract}

Key words: differentiation of plant communities, disturbances of habitat, habitat conservation status, indicators, monitoring, Natura 2000 , rural areas.

\section{Introduction}

Wet meadows of the Calthion palustris alliance are considered strongly endangered ecosystems in Poland as well as in other European countries (Mountford 1994; Brzeg \& Wojterska 1996; Grootjans et al. 1996, 2005; Schrauzer et al. 1996; Trąba \& Wolański 2011; Kurowski \& Kucharski 2012; Parusel et al. 2012). The decreasing of the habitat sites number and disturbances in the conservation status, due mainly to drainage and land-use changes, are commonly observed (Kotańska 1993; Barabasz 1994; Kucharski 1999; Kryszak et al. 2005; Babczyńska-Sendek 2009).

A significant chance of meadow ecosystems protection is provided by the agri-enviromental scheme, particularly because of its general accessibility. The programme pre- vents abandonment of agricultural lands as well as agricultural intensification, which are the most frequent causes of declining of the habitats in agricultural landscape.

The aim of the study is evaluation of conservation status and phytosociological differentiation of the wet meadows of the Calthion palustris alliance at sites covered by agri-environmental subsidies from package 4: "Protection of threatened bird species and natural habitats outside Natura 2000 sites" and package 5: "Protection of threatened bird species and natural habitats at Natura 2000 sites" (Rural Areas Development Programme 2007-2013). The possible causes of the observed disturbances and the representativeness of the obtained data of the Calthion palustris alliance meadows in Poland have been discussed. The study also attempted to determine the conservation prospects of 
the habitat allowing for the measures implemented under the agri-environmental scheme.

\section{Material and methods}

The paper presents the preliminary results of the first stage of monitoring (cf. Jarzombkowski et al. 2015a) of the Calthion palustris alliance meadows at sites covered by agri-environmental subsidies from packages 4 and 5. The research was conducted from May to August in 2012-2014 and covered 697 sites located all over the area of Poland.

The study methods were developed at the Institute of Technology and Life Sciences (Jarzombkowski et al. 2015 b) on the basis of methodical assumptions used by the Chief Inspectorate of Environmental Protection for monitoring of Natura 2000 natural habitats under the National Environmental Monitoring (Mróz 2010).

The sites for habitat monitoring were randomly selected from the pool of agri-environmental plots, which habitat and ornithological documentations were submitted to the Ministry of Agriculture and Rural Development. Agri-environmental habitat plots were selected every year out of the total number of 6827 parcels with the so-called "habitat variants" assigned for implementation in 2011-2014 (cf. Jarzombkowski et al. 2015a, b). Agri-environmental ornithological plots were randomly selected from 338 parcels with the so-called "bird variant" assigned for implementation from 2011 and previously selected for ornithological monitoring (Żmihorski 2014; Kotowska \& Żmihorski 2015).

Three experimental plots with the total area of 0.2 ha were laid out at each of the monitored parcels, covering patches of the habitat representative of a given parcel. Three relevés of $25 \mathrm{~m}^{2}$ each were made in the center of each plot using the Braun-Blanquet method. The relevés were completed with general description of vegetation, positive and negative factors affecting the habitat were determined as well as the habitat condition was assessed using specifically selected indicators and two parameters: "specific structure and habitat functioning" and "habitat conservation chances" (Table 1). The general assessment score, reflecting the overall status of a plot, is equal to the lower assessment score of the parameters. The list of indicators includes the so-called cardinal indicators, considered to be particularly important in the identification of habitat condition and obligatorily affecting the assessment of the parameter "structure and habitat functioning". The parameter "habitat conservation chances" was assessed based on the observed disturbances and interactions as well as possible prevention measures. For each of the indicators and parameters, the assessment was performed in accordance with the three-point scale:

status FV - favourable, status U1 - unfavourable-inadequate,

status U2 - unfavourable-bad.

In the case when it was not possible to determine the habitat condition in the context of a given indicator or parameter, the status $\mathrm{XX}$ - unknown - was assigned.

The frequency of species at the study plots was assessed according to Tansley's scale (Tansley 1946) by adopting the following degrees:

$\mathrm{d}$ - dominant - a species totally dominates other species;

c - co-dominant - a species co-dominates with other species;

a - abundant - a species occurs with high abundance, but is not a dominant;

$\mathrm{f}$ - frequent - a frequent species;

o - occasional - scattered occurrence;

$\mathrm{r}$ - rare - a rare species, i.e. a few-several specimens;

$\mathrm{s}-$ sporadic - a very rare occasional species: only single specimens;

ld - local dominant - a species locally totally dominates other species;

la - local abundant - a species locally occurs with high abundance, but is not a dominant;

If - local frequent - a locally frequent species.

In addition to fieldwork, surveys with owners or managers of the monitored plots were carried out. Information about the actual and past land management of the parcels was collected, e.g. frequency and timing of mowing as well as the number and type of grazing animals.

For the purpose of vegetation description, the syntaxonomy was accepted after Matuszkiewicz (2008).

\section{Results}

\subsection{Distribution of the monitored wet meadows of the Calthion palustris alliance}

After the field verification, it was found that wet meadows of the Calthion palustris alliance are most common in the western part of Poland (Fig. 1), including in particular Sudety Mountains, the Silesian-Lusatian Lowlands, Trzebnica Moraine Hills, Warta-Oder and Toruń-Eberswalde ice-marginal valleys, South Pomeranian, West Pomeranian and East Pomeranian Lake Districts as well as coastal regions: Koszalin Coast and Szczecin Coast (cf. Kondracki 2002). Many meadows are located in the Nida Basin and in the Kielce Upland as well as along the eastern border of the country, in the regions such as the Beskidy Lesiste Mountains, Roztocze, the Bug Basin, the Lublin and Volhynian Uplands, Volhynian and Western Polesie, the North Podlasie Lowland and the Lithuanian Lakeland.

Noteworthy is the lack or rare occurrence of monitored wet meadows in the region of Gdańsk Coast, the Old Prus- 
Table 1. Assessment of indicators and parameters for wet meadows of the Calthion palustris alliance; * - cardinal indicators

\begin{tabular}{|c|c|c|c|}
\hline $\begin{array}{l}\text { Indicators and param- } \\
\text { eters }\end{array}$ & Favourable status FV & Unfavourable-inadequate status U1 & Unfavourable-bad status U2 \\
\hline Characteristic species ${ }^{*}$ & 6 or more characteristic species & 4-5 characteristic species & 1-3 characteristic species \\
\hline Dominant species & $\begin{array}{l}\text { Characteristic species of the Calthion } \\
\text { palustris alliance and the Molinietalia } \\
\text { order occur abundantly; lack of expan- } \\
\text { sive species among the dominants }\end{array}$ & $\begin{array}{l}\text { Characteristic species of the Calthion } \\
\text { palustris alliance and the Molinietalia } \\
\text { order as well as other species co-dom- } \\
\text { inate; expansive species occur in cate- } \\
\text { gories a or ld acc. to Tansley's scale }\end{array}$ & $\begin{array}{l}\text { Dominants are represented by spe- } \\
\text { cies other than those of the Calthion } \\
\text { palustris alliance and the Molinietalia } \\
\text { order or expansive species of the said } \\
\text { alliance and order }\end{array}$ \\
\hline $\begin{array}{l}\text { Expansive species of her- } \\
\text { baceous plants * }\end{array}$ & $\begin{array}{l}\text { No expansive species present or only } \\
\text { in the o category acc. to Tansley's scale }\end{array}$ & $\begin{array}{l}\text { Expansive species occur in categories } \\
\text { lf, f, la or ld acc. to Tansley's scale }\end{array}$ & $\begin{array}{l}\text { Expansive species occur in categories } \\
\text { a, c or d acc. to Tansley's scale (expan- } \\
\text { sive species could be represented also } \\
\text { e.g. by Deschampsia caespitosa, Juncus } \\
\text { effusus, Polygonum bistorta, if they are } \\
\text { dominant species) }\end{array}$ \\
\hline Invasive alien species & $\begin{array}{l}\text { No alien species present or they occur } \\
\text { in categories s or } r \text { acc. to Tansley's } \\
\text { scale }\end{array}$ & $\begin{array}{l}\text { Alien species occur in the o category } \\
\text { acc. to Tansley's scale }\end{array}$ & $\begin{array}{l}\text { Alien species occur in categories lf, } \mathrm{f} \\
\text { la or ld acc. to Tansley's scale }\end{array}$ \\
\hline $\begin{array}{l}\text { Rare, protected, threatened } \\
\text { species }\end{array}$ & $\begin{array}{l}3 \text { or more rare/protected/threatened } \\
\text { species }\end{array}$ & 1-2 rare/protected/threatened species & $\begin{array}{l}\text { No rare/ } \\
\text { protected/threatened species present }\end{array}$ \\
\hline Indicator species & $\begin{array}{l}4 \text { or more indicator species (E and F } \\
\text { list - cf. Documentation... 2011, 2012, } \\
\text { 2013) occur in categories o, lf, f, la, a, } \\
\text { c, ld or d acc. to Tansley's scale }\end{array}$ & $\begin{array}{l}\text { 2-3 indicator species (E and F list - cf. } \\
\text { Documentation... 2011, 2012, 2013) } \\
\text { occur in categories o, lf, f, la, a, c, ld or } \\
\text { d acc. to Tansley's scale }\end{array}$ & $\begin{array}{l}\text { None or } 1 \text { indicator species (E and F } \\
\text { list - cf. Documentation... 2011, 2012, } \\
\text { 2013) occurring in categories o, lf, f, } \\
\text { la, a, c, ld or d acc. to Tansley's scale, } \\
\text { or more indicator species occurring in } \\
\text { categories s or } r \text { acc. to Tansley's scale }\end{array}$ \\
\hline Plant litter (felt) & $\begin{array}{l}\text { None or felt with a loose structure } \\
\text { (average thickness below } 0.5 \mathrm{~cm} \text { ) }\end{array}$ & $\begin{array}{l}\text { Small-thickness layer (average thick- } \\
\text { ness } 0.5-2 \mathrm{~cm} \text { ) }\end{array}$ & $\begin{array}{l}\text { The layer of medium or relatively large } \\
\text { thickness (average thickness above } \\
2 \mathrm{~cm} \text { ) }\end{array}$ \\
\hline Sward destruction & $\begin{array}{l}\text { Up to } 5 \% \text { destruction of the study } \\
\text { plots }\end{array}$ & $\begin{array}{l}\text { Destruction of } 5-20 \% \text { of the study } \\
\text { plots }\end{array}$ & $\begin{array}{l}\text { Over } 20 \% \text { destruction of the study } \\
\text { plots }\end{array}$ \\
\hline Drainage system ${ }^{*}$ & $\begin{array}{l}\text { None or drainage ditches present on } \\
\text { a parcel or at a distance of up to } 50 \mathrm{~m} \\
\text { from the boundaries of a parcel, ditch- } \\
\text { es completely overgrown with vege- } \\
\text { tation, a parcel is not situated within } \\
\text { a drained complex }\end{array}$ & $\begin{array}{l}\text { Drainage ditches are located on a par- } \\
\text { cel or at a distance of up to } 50 \mathrm{~m} \text { from } \\
\text { the boundaries of a parcel, their depth } \\
\text { less than } 0.5 \mathrm{~m} \text {; ditches deeper than } \\
0.5 \mathrm{~m} \text { have dams or natural barriers } \\
\text { or no drainage ditches on a parcel or at } \\
\text { a distance of } 50 \mathrm{~m} \text { from its boundaries, } \\
\text { but a parcel is located within a drained } \\
\text { complex }\end{array}$ & $\begin{array}{l}\text { Drainage ditches are located on a par- } \\
\text { cel or at a distance of up to } 50 \mathrm{~m} \text { from } \\
\text { the boundaries of a parcel; ditches are } \\
\text { deeper than } 0.5 \mathrm{~m} \text { or a parcel anjoin } \\
\text { on a canalised river }\end{array}$ \\
\hline $\begin{array}{l}\text { The presence of shrubs } \\
\text { and undergrowth of trees * }\end{array}$ & $\begin{array}{l}\text { No trees and shrubs or they occur in } \\
\text { categories s or } r \text { acc. to Tansley's scale } \\
\text { (specimens of trees and shrubs occur- } \\
\text { ring in sward should be included) }\end{array}$ & $\begin{array}{l}\text { Species of trees and shrubs occur in } \\
\text { the o category acc. to Tansley's scale } \\
\text { (specimens of trees and shrubs occur- } \\
\text { ring in sward should be included) }\end{array}$ & $\begin{array}{l}\text { Species of trees and shrubs occur in } \\
\text { categories lf, } f, \text { la, a, c, ld or } d \text { acc. to } \\
\text { Tansley's scale (specimens of trees and } \\
\text { shrubs occurring in sward should be } \\
\text { included) }\end{array}$ \\
\hline $\begin{array}{l}\text { Habitat coverage at the } \\
\text { study plots }\end{array}$ & $80-100 \%$ & $50-79 \%$ & below $50 \%$ \\
\hline Degree of habitat humidity & $\begin{array}{l}\text { Water level at or up to } 25 \mathrm{~cm} \text { below } \\
\text { the ground surface }\end{array}$ & $\begin{array}{l}\text { Water level } 25-50 \mathrm{~cm} \text { below the } \\
\text { ground surface }\end{array}$ & $\begin{array}{l}\text { Water level more than } 50 \mathrm{~cm} \text { below } \\
\text { the ground surface }\end{array}$ \\
\hline $\begin{array}{l}\text { STRUCTURE AND HABI- } \\
\text { TAT FUNCTIONING } \\
\end{array}$ & $\begin{array}{l}\text { All cardinal indicators were assessed } \\
\text { as FV, other indicators as FV or U1 }\end{array}$ & $\begin{array}{l}\text { At least one of the cardinal indicators } \\
\text { was assessed as U1, and none as U2 }\end{array}$ & $\begin{array}{l}\text { One or more cardinal indicators were } \\
\text { assessed as U2 }\end{array}$ \\
\hline $\begin{array}{l}\text { HABITAT'S } \\
\text { CONSERVATION } \\
\text { CHANCES }\end{array}$ & $\begin{array}{l}\text { Very good or good prospects of habitat } \\
\text { preservation, no significant impact of } \\
\text { threatening factors is expected }\end{array}$ & $\begin{array}{l}\text { There are possibilities of improving } \\
\text { the habitat condition e.g. through } \\
\text { active conservation measures }\end{array}$ & $\begin{array}{l}\text { Inability to improve the habitat con- } \\
\text { dition, a strong impact of threatening } \\
\text { factors observed }\end{array}$ \\
\hline GENERAL ASSESSMENT & Both parameters were assessed as FV & $\begin{array}{l}\text { At least one of the parameters was } \\
\text { assessed as U1, and none as U2 }\end{array}$ & $\begin{array}{l}\text { At least one of the parameters was } \\
\text { assessed as U2 }\end{array}$ \\
\hline
\end{tabular}




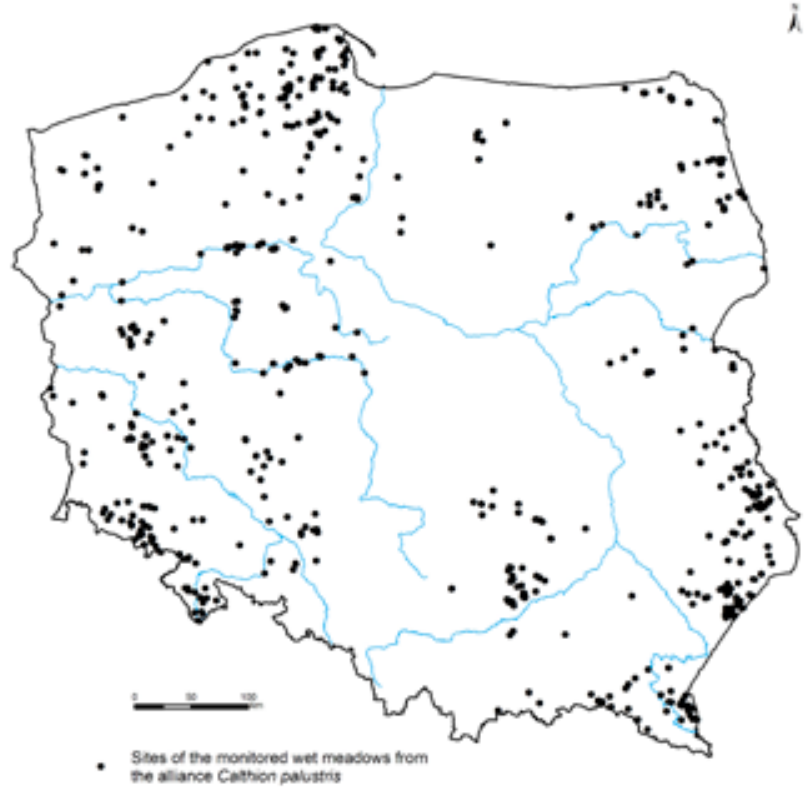

Figure 1. Distribution of the parcels with the monitored wet meadows of the Calthion palustris alliance

sian Lowland, the Masurian Lakeland, Iława and Chełmno-Dobrzyń Lake Districts, the central part of the Central Polish Lowlands (North and Central Mazovian Lowlands, South Mazovian Heights, part of the South Wielkopolska Lowland), Małopolska and Silesia-Kraków Uplands, the Northern Subcarpathia, the West-Beskidy Piedmont as well as the Western Beskidy Mountains and the Central Western Carpathian Mountains.

\subsection{The land use of parcels}

Seventy percent of parcels, at which wet meadows of the Calthion palustris alliance were monitored, are covered by agri-environmental variant 4.6/5.6 Seminatural wet meadows. In accordance with the Regulation of the Minister of Agriculture and Rural Development (cf. Regulation...2013), the main requirements of variant 4.6/5.6 anticipate extensive hay making with one or two mowings per year carried out from 15 June to 30 September, or hay making and grazing with livestock density (stocking of animals) of up to $1 \mathrm{LSU} /$ ha and the grazing capacity of up to $5 \mathrm{t} /$ ha $(10 \mathrm{LSU} / \mathrm{ha})$ from 21 July to 15 October. Six percent of the surveyed wet meadows are covered by variant 4.7/5.7 Seminatural mesic meadows, whose requirements regarding the management are the same as in the case of variant 4.6/5.6. The information provided by owners indicates that hay making is implemented at $84 \%$ of the parcels covered by variants $4.6 / 5.6$ and $4.7 / 5.7$, and at the remaining $16 \%$ - hay making and grazing (in single cases - grazing), mostly cattle grazing. One mowing per year is carried out at $75 \%$ of parcels with hay meadows, and two mowings - at $25 \%$ of the parcels.
Twelve percent of the monitored wet meadows are located at parcels included in variant 4.1/5.1 Protection of bird breeding habitats, at which hay making can be carried out after 1 August, and grazing - from May to 15 October with the livestock density of up to 0.5 LSU till 20 July and 0.5-1 LSU after 20 July, and the grazing capacity of up to $5 \mathrm{t} /$ ha (10 LSU/ha). The hay-making and grazing land-use type is also acceptable, with mowing carried out from 1 August to 30 September and grazing from May to 15 October, with stocking of up to $0.2 \mathrm{LSU}$ and grazing capacity of up to $5 \mathrm{t} / \mathrm{ha}$ (10 LSU/ha).

Due to heterogeneous vegetation or mistakes made by experts during the classification of parcels into the agri-environmental scheme, $12 \%$ of the monitored wet meadows were covered by other variants, which involves other landuse types implemented on the parcels. Requirements of these variants assume a significantly more extensive use of wet meadows, with mowing carried out less frequently and at a later date, without grazing and fertilizing. Those are:

- variant 4.2/5.2 Sedge-moss communities - mowing carried out every two years or at $50 \%$ of a parcel every year after 15 July ( $4 \%$ of the sites);

- variant 4.3/5.3 Tall-sedge communities (Magnocaricion) - mowing at $20 \%$ of a parcel every year after 15 July ( $5 \%$ of the sites);

- variant 4.4/5.4 Molinion and Cnidion meadows - mowing at $50 \%$ of a parcel every year after 15 September ( $2 \%$ of the sites);

- variant 4.10/5.10 Natural lands - no land use ( $1 \%$ of the sites).

Because the studies were performed in the early period of the agri-environmental commitment, the implementation of the criteria defined for a particular variant does not have yet a key importance for the habitat structure and functions. Nonetheless, they were taken into account when defining the perspectives of the habitat conservation.

\subsection{Phytosociological differentiation of plant communities}

A total of 2091 relevés were made at the monitored agri-environmental plots with wet meadows, including 46\% (952 relevés) representing well-developed associations of the Calthion palustris alliance. The remaining 54\% (1139 relevés) represented fragmentary developed forms of associations of the Calthion palustris alliance (24\%) as well as similar communities or communities occurring in the complex with vegetation of wet meadows $(30 \%)$. Spatial distribution of plant communities is presented in Figures 2-4.

Cirsietum rivularis (403 relevés) was the most common association of the Calthion palustris alliance whose phytocoenoses were observed in mountain, piedmont and upland areas as well as in the eastern and north-eastern part of the lowland. Plant communities representing the association 


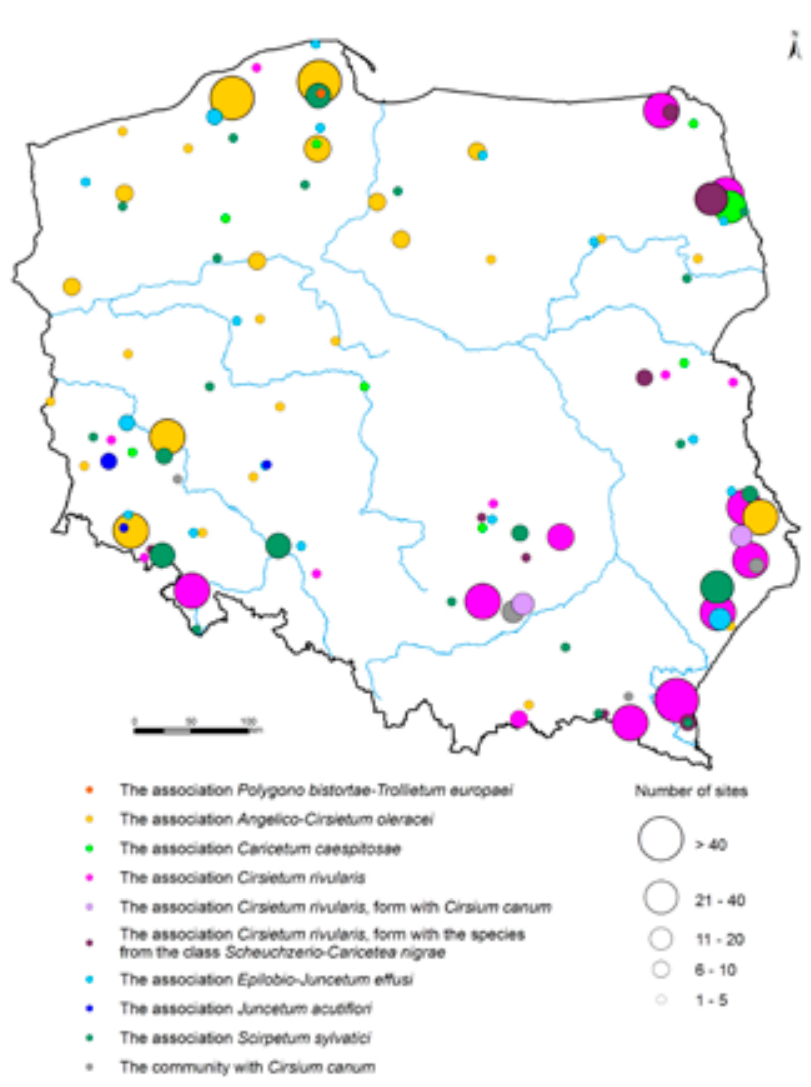

Figure 2. Distribution of associations of the Calthion palustris alliance. Circles represent clusters of relevés located at a distance no more than $20 \mathrm{~km}$ from each other; location of the centres of circles represents mean values of geographical coordinates of relevés

were rich in species and heterogeneous. For instance, the thermophilic form with Cirsium canum was distinguished, which occurs mostly in upland areas with limestone substrate, such as the Nida Basin and Lublin Upland, as well as the form with fen species of the Scheuchzerio-Caricetea nigrae class (usually low sedges characteristic for the Caricion nigrae and Caricion davallianae alliances), occurring mostly in mountain areas, in the Polesie region and in the Biebrza Basin.

The association Angelico-Cirsietum oleracei was represented by 271 relevés (13\%), distributed in the western part of Poland, mainly in the Sudety Mountain, the Silesian-Lusatian Lowlands, and the West-, East- and South Pomeranian Lake Districts as well as in the region of Koszalin Coast. Relatively many sites were found in Volhynian Polesie. At one site in the Kashubian Lake District, the association Polygono bistortae-Trollietum europaei was identified, the species composition of which resembles Angelico-Cirsietum oleracei, but differs in the presence of protected Trollius europaeus.

In many regions, phytocoenoses of the association Scirpetum sylvatici (129 relevés) were observed, usually in the

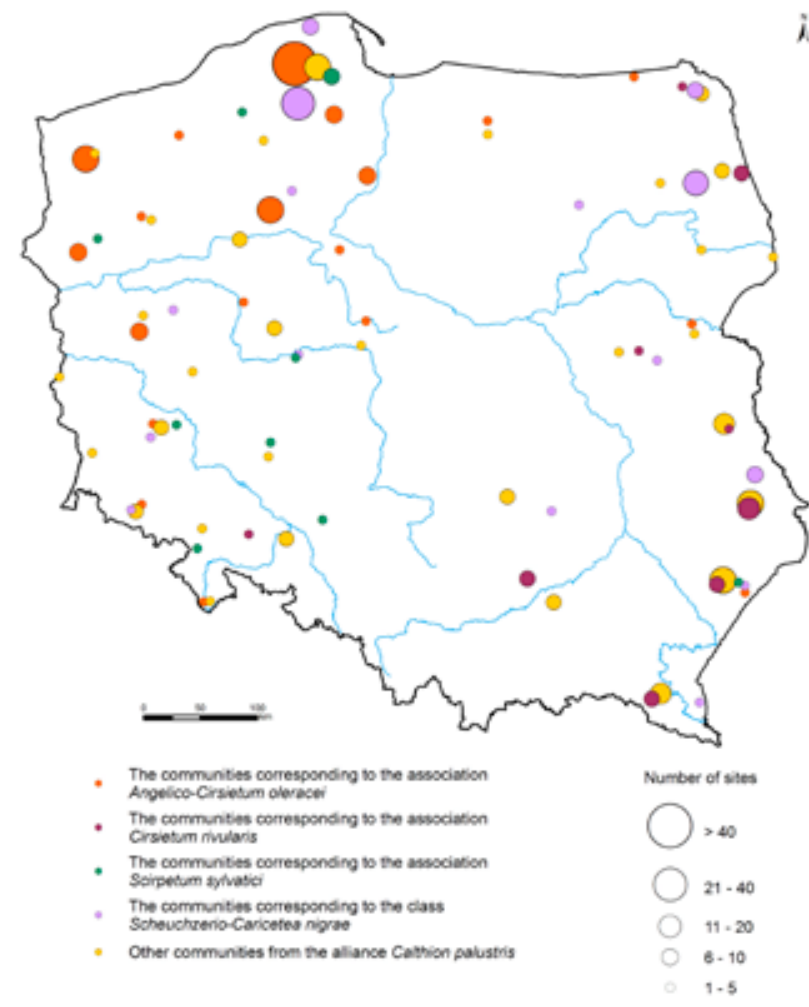

Figure 3. Distribution of the species-impoverished communities of the Calthion palustris alliance as well as the transitional forms between the Calthion palustris alliance and other phytosociological units

form of small patches in local topographic depressions or in seepage spring areas. Many sites of this vegetation were found e.g. in the Sudety Mountains, in the Silesian Lowland, in the Kashubian Lake District and in the region of Roztocze.

Phytocoenoses of the association Caricetum caespitosae (38 relevés) were observed relatively rarely. They occur throughout the country, but mainly in the peatland areas of the North Podlasie Lowland - particularly in the Biebrza Basin.

Communities with rushes (Juncus effusus and J. conglomeratus) as well as with the species characteristic for the Caricion nigrae alliance were found throughout the lowlands, and they were classified as the association Epilobio-Juncetum effusi. Despite their widespread occurrence, the number of sites with this type of vegetation is relatively small (68 relevés were made). Rush associations were most common in the Roztocze region, in the Silesian-Lusatian Lowland, in the coastal areas and in the South Baltic Lake District region.

Sites of the rare association Juncetum acutiflori (12 relevés) were found in the south-western part of the 


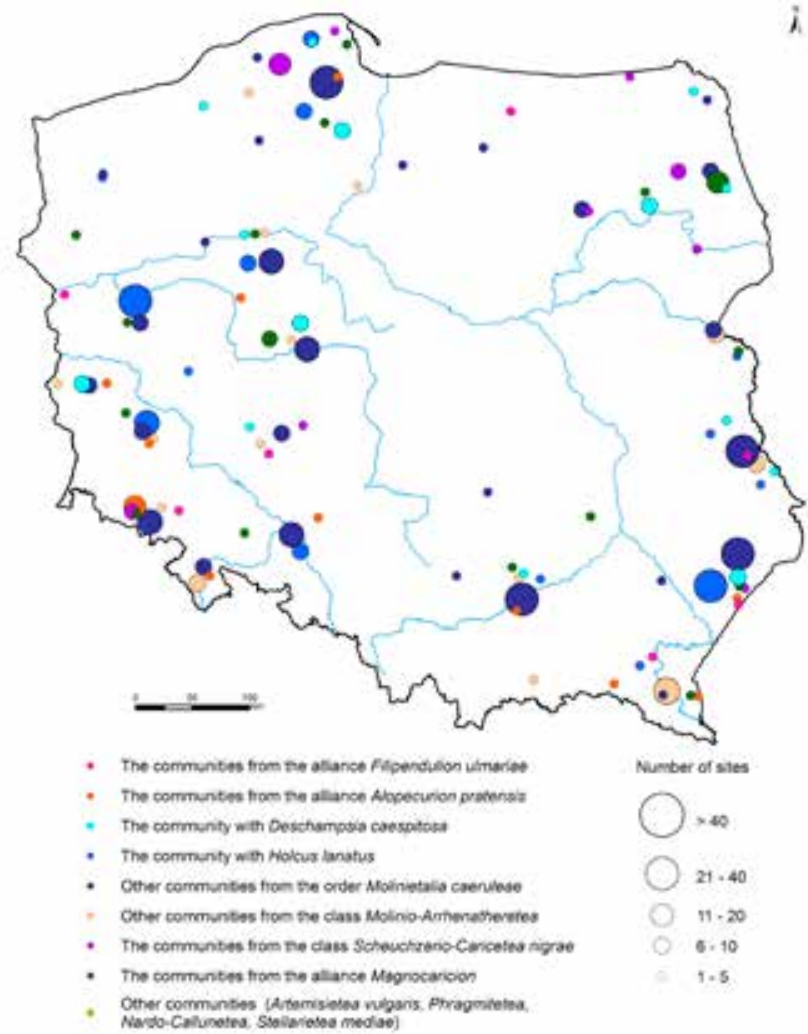

Figure 4. Distribution of other communities corresponding to or co-occurring with wet meadows of the Calthion palustris alliance

country, i.e. in the Jelenia Góra Basin, in the Lower Silesian Forests and in the Milicz-Głogów Basin.

Meadows with abundant contribution of Cirsium canum (classified as communities with Cirsium canum; 29 relevés) occur in the southern part of Poland. Compared to typical communities of the Calthion palustris alliance they usually develop on drier habitats. They were most frequently recorded in the Nida Basin, in the Volhynian Upland, and less frequently in the Silesian Lowland.

Distribution of species-impoverished communities is similar to the distribution of the listed associations. Species-impoverished communities of the Calthion palustris alliance were represented mostly by phytocoenoses corresponding to the association Angelico-Cirsietum oleracei (130 relevés). Phytocoenoses corresponding to the associations Cirsietum rivularis (55 relevés) and Scirpetum sylvatici (24 relevés) were less frequently encountered. This reflects the particularly high incidence of disturbances in the habitat conditions of areas covered by the association Angelico-Cirsietum oleracei. A total of 87 relevés, located mainly in the South Pomeranian Lake District and in the North Podlasie Lowland, represent communities corresponding to the Scheuchzerio-Caricetea nigrae class, usually small-sedge communities of the Caricion nigrae and Caricion davallianae alliances.
Other communities resembling or occurring in the complex with wet meadows of the Calthion palustris alliance are usually phytocoenoses of the Molinietalia caeruleae order dominated by grass species: Holcus lanatus, Deschampsia caespitosa, Alopecurus pratensis, Festuca rubra, Anthoxanthum odoratum. They are represented by 461 relevés, which makes up $22 \%$ of all relevés. They occur almost throughout the country except for the North Podlasie Lowland, in particular in Roztocze and Polesie, in the Nida Basin as well as in the river valleys of the Warta and the Noteć in the Wielkopolska Lake District and in the Torun-Eberswalde ice-marginal valley. They are connected with drained meadows and riparian areas. A total of 62 relevés come from other communities of the Molinio-Arrhenatheretea class, e.g. mesic meadows of the Arrhenatheretalia order and the Poa pratensis-Festuca rubra community. They occur mostly in the mountains (Sudety Mountains, Beskidy Lesiste Mountains) where due to the land relief, they often form mosaic patterns with wet and mesic meadows. In the Sudety, the Biebrza Basin, the West Pomeranian Lake District and on the Koszalin Coast, fen communities resembling wet meadows were observed; they belong to the Scheuchzerio-Caricetea nigrae class, mostly low-sedge meadows of the Caricion nigrae alliance (44 relevés). Furthermore, communities of tall-sedge communities of the Magnocaricion alliance (48 relevés) occur in the lowland regions, particularly in the North Podlasie Lowland, but also in the Wielkopolska Lake District. Other communities (inter alia of the Artemisietea vulgaris and Nardo-Callunetea classes) were recorded occasionally.

\subsection{Habitat conservation status}

Both the overall habitat assessment, as well as the structure and habitat functioning were assessed low (Fig. 5). Only ca. $10 \%$ of the sites with wet meadows were assessed as favourable, whereas more than $50 \%$ of the sites were assessed as unfavourable-bad due to heavily disturbed structure and functioning. The future prospects of the habitat were assessed more positively - for most of the parcels, the conservation of wet meadows appears feasible, at least in the current state.

The reason for unfavourable assessment of the habitat condition are disturbances, the presence of which can be observed in the analysis of the evaluated indicators (Fig. 6). The cardinal indicators: "characteristic species", "expansive species of herbaceous plants" and "drainage system" were assessed least positively. Also the habitat condition in terms of additional indicators such as "dominant species", "rare, protected, threatened species", " the degree of habitat humidity" and "plant litter" were assessed unfavourably. On the other hand, no significant threats in the form of geographically alien species invasion, encroachment trees and shrubs or destruction of sward were identified. 
Indicator "characteristic species". This cardinal indicator had the lowest assessment scores, which evidences the rare occurrence of species typical for the habitat within the surveyed meadows of the Calthion palustris alliance. Characteristic species were least frequent in old-glacial lowland areas, slightly more common in lakeland and upland regions, while most common in submontane and montane areas. At $30 \%$ of the monitored sites, the status of wet meadows in the context of this indicator was evaluated as favourable (FV), at $39 \%$ of the sites - as unfavourable-inadequate (U1) and at 31\% - as unfavourable-bad (U2). The most common characteristic species were as follows: Juncus effusus (355 parcels), Caltha palustris (318 parcels) and Scirpus sylvaticus (318 parcels), Myosotis palustris (295 parcels), Cirsium rivulare (294 parcels), Cirsium oleraceum (282 parcels) and Polygonum bistorta (279 parcels), the least common were Juncus acutiflorus (15 parcels), Bromus racemosus (4 parcels) and Trollius europaeus (3 parcels).

Indicator "dominant species". Assessment of this indicator allowed for the contribution of characteristic and expansive species as well as the overall typicality of floristic composition of a plant community. The floristic composition at $51 \%$ of the sites was assessed as favourable (FV status), at $36 \%$ - as unfavourable-inadequate (U1 status), and at $13 \%$ - as unfavourable-bad (U2 status). The analysed habitat patches were dominated by grass species resistant to high fluctuations of the groundwater level. The following dominant species were most frequently recorded: Holcus lanatus (205 parcels), Ranunculus repens (130 parcels), Festuca rubra (123 parcels), Alopecurus

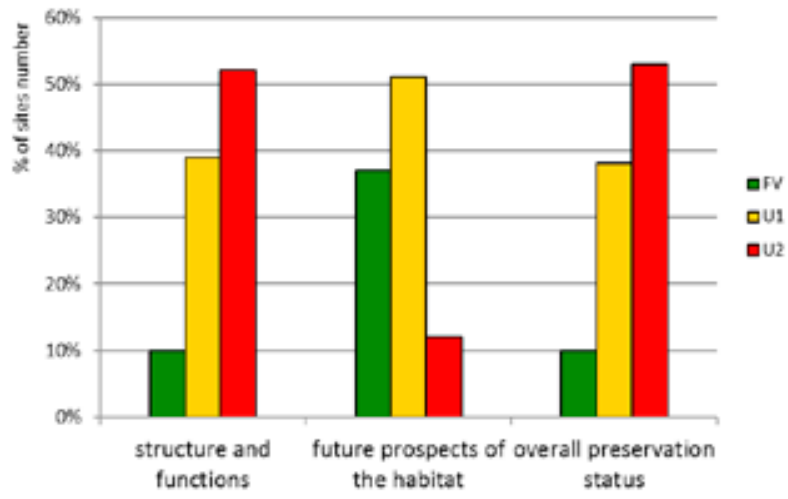

Figure 5. Assessment of the parameters and the overall assessment of wet meadows of the Calthion palustris alliance

pratensis (117 parcels) and Deschampsia caespitosa (103 parcels), and of the characteristic species of the Calthion palustris alliance: Scirpus sylvaticus (118 parcels) and Cirsium rivulare (103 parcels).

Indicator "expansive species of herbaceous plants". Distribution of the assessment scores of this indicator shows that nearly half of the monitored parcels were covered by expansive species of herbaceous plants in the extent threating the habitat. Lack or single specimens were found at $52 \%$ of the monitored sites (FV status), moderate expansion was observed at $30 \%$ of the surveyed parcels (U1 status), and the dominance of expansive species - at $18 \%$ (U2 status). This phenomenon was observed in all regions of Poland, although with lower intensity in mountain and submontane areas. Tall-herbaceous and nitrophilous spe-

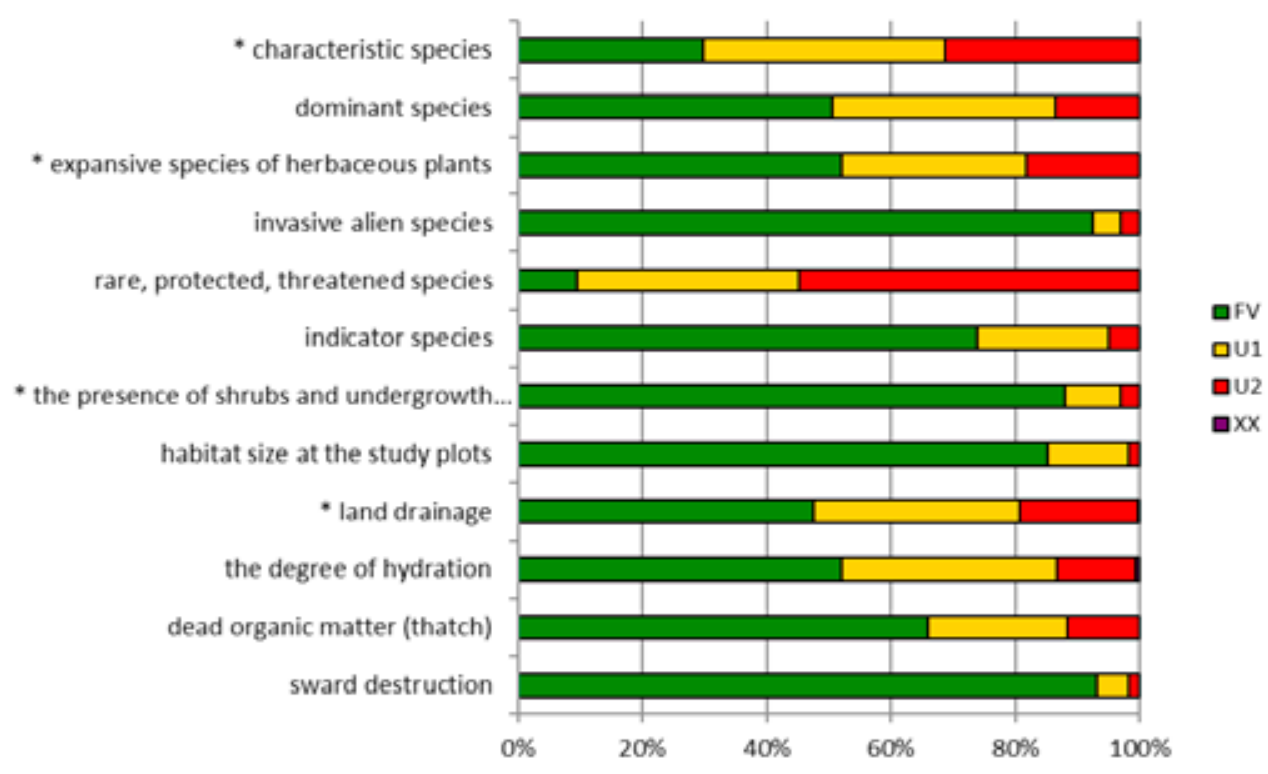

Figure 6. Distribution of habitat assessment scores in respect of individual indicators; * - cardinal indicators 
cies were most frequently reported, including in particular Urtica dioica (136 parcels), Filipendula ulmaria (87 parcels), Cirsium arvense (86 parcels) as well as rush species - Phragmites australis (100 parcels) and Phalaris arundinacea (97 parcels). The expansion of Calamagrostis epigejos, Eupatorium cannabinum, Anthriscus sylvestris and Carex brizoides was less frequently observed. Furthermore, meadows dominated by expansive grasses (mainly Deschampsia caespitosa and Holcus lanatus) were also found.

Indicator "invasive alien species". Encroachment of invasive, geographically alien species seldom threatened the habitat. At $92 \%$ of the sites, this risk was not observed at all (FV status), at $5 \%$ of the sites - to a minor extent only (U1 status), and at 3\% of the sites - alien species invasion posed a major threat (U2 status), most often by Solidago canadensis and Solidago gigantea.

Indicator "rare, protected, threatened species". This indicator got the lowest assessment score among all the analysed characteristics of the surveyed wet meadows. However, lack of valuable floristic elements in the communities of the Calthion palustris alliance does not necessarily mean their degeneration. In this context, the favourable habitat preservation status of this indicator was determined at $9 \%$ of all parcels (status FV), unfavourable-inadequate status - at 36\% (status U1), and unfavourable-bad (status U2) - at 55\%. The localities of rare and protected species were found mainly in mountain and piedmont meadows where, for instance, the following species occur: Colchicum autumnale, Primula elatior, Veratrum lobelianum as well as numerous species from the orchid family: Dactylorhiza majalis, Platanthera bifolia, Listera ovata and Gymnadenia conopsea. On the other hand, upland areas are distinguished by the presence of species associated with the limestone substrate, i.e. Carex davalliana and Sesleria uliginosa as well as numerous sites of Ostericum palustre.

Indicator "indicator species". It applies to the occurrence of so-called indicator species, classifying the habitat as variant 4.6/5.6 Seminatural wet meadows (Documentation... 2011, 2012, 2013). At $74 \%$ of the parcels, the contribution of indicator species was considered to be favourable (FV status), at 21\% - unfavourable-inadequate (U1 status), and at 5\% - unfavourable-bad (U2 status). A significantly larger number of indicator species occurs in mountain and upland areas, which is related to the fact that wet meadows in these areas occur far more often in the complex with mesic meadows. Whereas, methods of selecting the agri-environmental habitat parcels (Documentation... 2011, 2012 , 2013) recognize the so-called indicator species of mesic meadows as relevant also to wet meadows. On the other hand, in most lowland areas, wet meadows occur in a mosaic with reed beds, peat bogs or meadows with varying moisture conditions, and not with mesic meadows.

Indicator "the presence of shrubs and undergrowth of trees". Encroachment of trees and shrubs was seldom observed at the monitored parcels and only in few cases it was a far-reaching expansion. This seems obvious because a parcel can become entirely overgrown with trees and shrubs only with the complete absence of agricultural use, which is a rare case in areas covered by the agri-environmental scheme. No expansion of trees or bushes was observed at $88 \%$ of the parcels (FV status), moderate expansion - at 9\% (U1 status), and major expansion - at 3\% (U2 status). The parcels were most frequently overgrown with Salix cinerea and other willows Salix spp., as well as with Alnus glutinosa and Frangula alnus.

Indicator "habitat size at the study plots". Phytocoenoses of the monitored habitat covered at least $80 \%$ of the total parcel area at $85 \%$ of the monitored sites (FV status) and less than $50 \%$ at only $2 \%$ of the sites (U2 status). This means that phytocoenoses were generally large and compact.

Indicator "drainage system". This indicator is a measure of the impact exerted by a drainage system on the habitat condition. No negative impact of the drainage infrastructure was observed at $48 \%$ of the monitored sites (FV status), minor impact - at 33\% of the sites (U1 status), and strong impact - at $19 \%$ of the parcels (U2 status). In rare cases (less than 1\%), the impact of drainage was considered impossible to determine (XX status). The strongest impact of the drainage systems was observed in lake districts of northern Poland, while the least impact in areas of the mountain and piedmont meadows. Drainage of habitats can be caused not only by ditches, but also by ponds created in meadow complexes and channelled water courses.

Indicator "degree of habitat humidity". Low water table level of wet meadows has been mostly associated with land drainage, but it could also result from natural conditions (e.g. in mountain areas where moisture content decreases uphill or with the increasing distance from a water seepage site) or other phenomena, e.g. the presence of depression cones. The degree of hydration was considered favourable at $52 \%$ of the monitored sites (FV status), minor, perhaps temporary deterioration (U1 status) at 35\% of the sites, and significant desiccation (U2 status) at $13 \%$ of the sites. In rare cases (less than 1\%), the degree of hydration was considered impossible to determine (XX status). Most of the dry meadows occur in lakeland and upland regions, slightly less in lowland regions, while the most favourable water conditions of habitats occur in mountain and piedmont areas.

Indicator "plant litter (felt)". Accumulation of the dead organic matter may result from extensive use or lack thereof, or the biomass left at a site after mowing. The presence of the felt layer of a moderate thickness (U1 status) was found at $22 \%$ of the monitored sites, and the layer of considerable thickness (U2 status) - at $12 \%$ of the sites. No accumulation of organic matter was determined at $66 \%$ of the sites. 
Indicator "sward destruction". Destruction of sward on wet meadows is caused mostly by wild boar rooting or ruts left by agricultural machinery. None or minor destruction (FV status) was observed at most of the parcels (93\%), up to $20 \%$ of the total parcel area was destroyed (U1 status) at $5 \%$ of the sites, and more than $20 \%$ of the total parcel area (U2 status) - at $2 \%$ of the sites.

\section{Discussion}

\subsection{Plant communities of the monitored wet meadows in relation to the differentiation of plant communities of the Calthion palustris alliance in Poland}

Wet meadows of the Calthion palustris alliance in areas covered by variants 4 and 5 of the agri-environmental scheme are characterised by high vegetation diversity and considerable contribution of fragmentary or atypically developed phytocoenoses. Most of the Calthion palustris communities known from Poland (cf. Matuszkiewicz 2008; Trąba \& Wolański 2011), both widespread and limited in their range, occur on the monitored agri-environment parcels. The results of the research confirm the phenomena described in the literature, such as vicariance of the associations Angelico-Cirsietum oleracei and Cirsietum rivularis (Kucharski 1999; Matuszkiewicz 2008; Trąba \& Wolański 2011), floristic richness and great natural values of phytocoenoses representing the association Cirsietum rivularis (Denisiuk \& Korzeniak 1999; Babczyńska-Sendek 2009) as well as the abundant occurrence of phytocoenoses representing the association Caricetum caespitosae on peatlands in the Biebrza River valley (Pałczyński 1975; Oświt 1991). The association Epilobio-Juncetum effusi was identified in the lowland regions, mostly in phytocoenoses with Carex nigra and other species characteristic for the Caricion nigrae alliance, described previously e.g. from the Niepołomice Forest (Barabasz 1997), Silesian Upland (Suder 2007) and Lublin Region (Fijałkowski \& Chojnacka-Fijałkowska 1990). Sites of rare communities in Poland were documented, such as the Subatlantic association Juncetum acutiflori occurring mainly in the western and southern part of the country (Hryncewicz 1964; Nowiński 1967; Suder 2007; Rosadziński \& Brzeg 2013), as well as the thermophilic community with Cirsium canum (Fijałkowski 2003; Wójcik \& Kotańska 2014), occurring mainly on the carbonate substrate in upland areas.

In some cases, the small contribution of characteristic species of the Calthion palustris alliance was caused by the occurrence of transitional communities between wet meadows and other habitats - usually tall-sedge communities of the Magnocaricion alliance, mesic meadows of the Arrhenatheretalia order and sedge-moss communities of the Scheuchzerio-Caricetea nigrae class; such commu- nities may be characterised by high natural values and rich floristic composition. More often, however, fragmentary developed phytocoenoses of wet meadows of Molinietalia order were observed, impoverished as a result of habitat desiccation or too intensive management in the past. Out of the two main associations of the Calthion palustris alliance, impoverished, fragmentary or atypical forms of the association Angelico-Cirsietum oleracei were encountered more often (mainly in the coastal regions and in the South Baltic Lake Districts) compared to the association Cirsietum rivularis; the latter was represented by a larger number of monitored sites. Degeneration of the Angelico-Cirsietum oleracei association was described from northern Poland, e.g. from the Staniszewo Upland (Herbich 1982) and Tuchola Forest (Stosik 2014), and the habitat desiccation was determined as a likely cause of this phenomenon.

In many cases, the monitored habitat was represented by communities from the Molinietalia order corresponding to the Calthion palustris alliance and dominated by grass species: Holcus lanatus, Deschampsia caespitosa, Alopecurus pratensis, Festuca rubra and Anthoxanthum odoratum. Such vegetation is typical for dry and over-fertilized meadows developing on drained wetlands and in river valleys. In many regions of Poland, they represent the most common meadow communities (Grynia 1971; Mosek \& Jargiełło 1986; Fijałkowski \& Chojnacka-Fijałkowska 1990; Kotańska 1993; Brzeg \& Wojterska 1996; Kucharski 1999; Bartoszuk et al. 2001; Kryszak 2001; Kryszak et al. 2005; Kamiński 2008; Trąba \& Wolański 2011).

\subsection{Disturbances in the habitat conservation status}

In $90 \%$ of the cases, the overall assessment of the monitored wet meadows was considered as more or less affected. The most common effects included:

- small contribution of species characteristic for the habitat, which could reflect habitat drainage or intensive use in the past, using treatments that interfere in the structure of sward e.g. ploughing, harrowing, overseeding, over-fertilization (Barabasz 1994; Antkowiak 1996; Kucharski 1999);

- expansion of native herbaceous species, which could be associated with too extensive exploitation or lack thereof in recent years, or eutrophication of the habitat as a consequence of muck formation or nutrients runoff from the surrounding fields;

- desiccation of the substrate, mostly as a result of land drainage.

The unfavourable-bad habitat status in respect of characteristic species was determined at $31 \%$ of the parcels, and in respect of other factors - at $13-19 \%$ of the parcels. On the other hand, the overall unfavourable-bad habitat assessment was determined at over $50 \%$ of the monitored parcels, which shows that in many cases the aforemen- 
tioned effects do not occur at the same parcels. And thus, despite strong drainage, characteristic combination of species of the Calthion palustris alliance occurs on meadows developed on drained peatlands. These communities were probably formerly characterised by high natural values, but at present their condition deteriorates as a result of e.g. muck formation. On the other hand, phytocoenoses with a negligible contribution of characteristic species occur in areas where desiccation of the substrate was insignificant, which was probably caused by agricultural practices implemented in the past. Meadows with high water table level represent a different situation - they are seldom mown due to the inaccessibility to agricultural machinery. Consequently, the vegetation is dominated by expansive tall-herbaceous, rush or nitrophilous species.

\subsection{Representativeness of the results for wet meadows of the Calthion palustris alliance in Poland}

Due to the large number and high differentiation of the monitored plant communities distributed nearly all over the country, the presented results can be considered as representative for wet meadows of the Calthion palustris alliance in Poland. They differ from the results obtained under the National Environmental Monitoring GIOŚ for habitat 65XX (Korzeniak 2013), where preservation status of wet meadows was assessed significantly higher: $20 \%$ $-\mathrm{FV}, 61 \%$ - U1, $19 \%$ - U2 in the continental region and $27 \%-\mathrm{FV}, 67 \%-\mathrm{U} 1,6 \%-\mathrm{U} 2$ in the alpine region. The most pronounced differences are in the evaluation of the indicator "characteristic species" - the habitat condition at almost $80 \%$ of the sites monitored by GIOŚ was assessed as favourable in the context of this indicator. The differences between the results of both monitoring projects may result from slightly different methods applied in the evaluation of this indicator and in the selection of the sites. In the National Environmental Monitoring, phytocoenoses representing a variant of the association Angelico-Cirsietum oleracei or Cirsietum rivularis typical for a given region were selected individually for monitoring, whereas in the monitoring of habitats covered by the agri-environmental scheme, sites were randomly selected from parcels classified mainly based on the presence of indicator species. This kind of selection of the study sites resulted in a large contribution of phytocoenoses corresponding to the habitat and those atypically developed. And thus, it can be concluded that wet meadows researched under the National Environmental Monitoring are representative communities in terms of the phytosociological criterion, whereas wet meadows researched under the monitoring of environmental effects of the agri-environmental scheme are communities that actually dominate in rural areas and which can be willingly used by farmers.

\subsection{Prospects for habitat conservation in the context of packages 4 and 5 of the agri-environmental scheme}

Chances of preserving wet meadows were assessed by researchers of the monitoring project as relatively positive, mainly due to the fact that the plots were included in the agri-environmental scheme whose objective is e.g. to prevent the degradation of natural habitats. Implementation of the criteria from packages 4 and 5 (the Regulation... 2013) should ensure the implementation of the following conservation objectives:

- maintenance of the land use consisting in regular, extensive hay-making and grazing which prevent succession of meadow communities, encroachment of expansive and geographically alien species, as well as accumulation of plant litter;

- prevention of excessive intensification of land use, including mechanical and chemical interference in the habitat structure through implementation of the criteria such as: no ploughing, no rolling or overseeding, no wastewater and sewage sludge as well as reduction of fertilization up to $60 \mathrm{~kg} \mathrm{~N} / \mathrm{ha}$ per year.

On the other hand, the agri-environmental scheme implemented in the financial perspective of 2007-2013 did not ensure the criteria of preventing the habitat desiccation processes, which were one of the main factors deteriorating the habitat condition. The proper groundwater level on drained habitats is not ensured by the scheme's criteria, because the construction of new drainage systems and the expansion of the existing systems are prohibited, but the influence of already existing systems is not prevented. The programme is also ineffective in the case of large-scale land reclamation, implemented by units of local authorities.

Furthermore, the implemented measures may be insufficient on meadows classified into incorrect variants of the agri-environmental scheme. Such plots are mown once a year or less frequently, which can reduce the negative impact of no land-use, but probably will not improve the habitat condition. If the vegetation is dominated by expansive species or in the case of over-eutrophication, mowing once a year carried out on parcels covered by variant 4.6/5.6 Seminatural wet meadows may also prove ineffective.

\section{Conclusions}

a) The wet meadows, occurring at sites covered by agri-environmental subsidies from packages 4 and 5 , show high differentiation of plant communities, which can be considered as representative of meadows of the Calthion palustris alliance in Poland. 
b) In most of the cases, the structure and habitat functioning of wet meadows are disturbed due to drainage or unfavourable land-use. It is confirmed also by other research, which indicates bad conservation status of the Calthion palustris alliance meadows in Poland.

c) Implementation of the agri-enviromental scheme criteria should ensure maintenance of extensive land use and prevention of excessive agricultural intensification, but it is ineffective in some respects, above all of ensuring the proper groundwater level.

\section{Acknowledgements}

The research was carried out as part of the monitoring of environmental effects of the agri-environment scheme funded as one of the long-term programme's measures: "Standardization and monitoring of environmental projects, agricultural technology and infrastructural solutions for security and sustainable development of agriculture and rural areas", implemented by the Institute of Technology and Life Sciences.

\section{References}

Antkowiak W., 1996, Charakterystyka fitosocjologiczna wybranych łąk Wielkopolskiego Parku Narodowego [Phytosociological description of selected meadows in Wielkopolski National Park], Roczniki AR w Poznaniu 284: 141-155.

Babczyńska-Sendek B., 2009, Significance of protection of the meadow and grassland communities for maintenance the floristic diversity in the area of the south-eastern Silesian Upland (Poland), Biodiv. Res. Conserv. 13: 49-60.

Barabasz B., 1994, Wpływ modyfikacji tradycyjnych metod gospodarowania na przemiany roślinności łąk z klasy Molinio-Arrhenatheretea [The effect of modification of the traditional farming methods on Molinio-Arrhenatheretea grassland vegetation], Wiad. Bot. 38 (1/2): 85-94.

Barabasz B., 1997, Zmiany roślinności łąk w północnej części Puszczy Niepołomickiej w ciągu 20 lat [Changes in the grassland vegetation in the northern part of Niepołomice Forest over 20 years], Studia Naturae 43: $1-99$.

Bartoszuk H., Dembek W., Jezierski T., Kamiński J., Kupis J., Liro A., Nawrocki P., Sidor T. \& Wasilewski Z., 2001, Spasanie podmokłych łąk w dolinach Narwi i Biebrzy jako metoda ochrony ich walorów przyrodniczych [Grazing of wet meadows in the Narew and Biebrza river valleys as a method of their protection], Wydawnictwo IMUZ, Falenty.
Brzeg A. \& Wojterska M., 1996, Przegląd systematyczny zbiorowisk roślinnych Wielkopolski wraz z oceną stopnia ich zagrożenia [A systematic review of plant communities in the Wielkopolska Region and assessment of threats they are exposed to], Bad. Fizjogr. nad Polską Zachodnią, Series B, 45: 7-40.

Denisiuk Z. \& Korzeniak J., 1999, Zbiorowiska nieleśne Krainy Dolin Bieszczadzkiego Parku Narodowego [Non-forest plant communities in Kraina Dolin (Land of Valleys) in Bieszczady National Park], Monografie Bieszczadzkie 5: 1-162.

Dokumentacja przyrodnicza siedliskowa dla pakietów przyrodniczych w ramach programu rolnośrodowiskowego 2007-2013 [Natural habitat documentation for nature packages under the agri-environmental programme 2007-2013], 2011, Ministerstwo Rolnictwa i Rozwoju Wsi [The Ministry of Agriculture and Rural Development], Warszawa, http://www.minrol.gov.pl [Accessed 19.10.2015].

Dokumentacja przyrodnicza siedliskowa dla pakietów przyrodniczych $\mathrm{w}$ ramach programu rolnośrodowiskowego 2007-2013 [Natural habitat documentation for nature packages under the agri-environmental programme 2007-2013], 2012, Ministerstwo Rolnictwa i Rozwoju Wsi [The Ministry of Agriculture and Rural Development], Warszawa, http://www.minrol.gov.pl [Accessed 19.10.2015].

Dokumentacja przyrodnicza siedliskowa dla pakietów przyrodniczych $\mathrm{w}$ ramach programu rolnośrodowiskowego 2007-2013 [Natural habitat documentation for nature packages under the agri-environmental programme 2007-2013], 2013, Ministerstwo Rolnictwa i Rozwoju Wsi [The Ministry of Agriculture and Rural Development], Warszawa, http://www.minrol.gov.pl [Accessed 19.10.2015].

Fijałkowski D., 2003, Ochrona przyrody i środowiska na Lubelszczyźnie [Nature and habitat protection in the region of Lublin], Lubelskie Towarzystwo Naukowe, Lublin.

Fijałkowski D. \& Chojnacka-Fijałkowska E., 1990, Zbiorowiska z klas Phragmitetea, Molinio-Arrhenatheretea i Scheuchzerio-Caricetea fuscae w makroregionie lubelskim [Plant communities of the classes Phragmitetea, Molinio-Arrhenatheretea and Scheuchzerio-Caricetea fuscae in the Lublin macroregion], Roczn. Nauk Roln., series D, 217: 1-411.

Grootjans A.P., Fresco L.F.M., Leeuw C.C. \& Schipper P.C., 1996, Degeneration of species-rich Calthion palustris hay meadows; some considerations on the community concept, Journal of Vegetation Science 7: 185-194.

Grootjans A.P., Hunneman H., Verkiel H. \& Van Andel J., 2005, Long-term effects of drainage on species richness 
of a fen meadow at different spatial scales, Basic and Applied Ecology 6: 185-193.

Grynia M., 1971, Charakterystyka geobotaniczna łąk śmiałkowych na przykładzie niektórych dolin Polski Zachodniej [Geobotanical description of Deschampsia meadows occurring in selected valleys of Western Poland], Prace Kom. Nauk Roln. Kom. Nauk Leśn. PTPN 31: 223-239.

Herbich J., 1982, Zróżnicowanie i antropogeniczne przemiany roślinności Wysoczyzny Staniszewskiej na Pojezierzu Kaszubskim [Differentiation and anthropogenic transformations of vegetation in Staniszewo Upland, the Kashubian Lake District], Monographiae Botanicae 63: 1-162.

Hryncewicz Z., 1964, Asocjacje roślinne łąk śródleśnych w Borach Dolnośląskich [Plant associations of forest meadows in Lower Silesian Forests], Roczn. Nauk Roln., series D, 110: 1-85.

Jarzombkowski F, Gutowska E., Kazuń A., Kowalska M., Kotowska D., Kotowska K., Krajewski Ł., Piórkowski H., Szczepaniuk A., Topolska K. \& Żmihorski M., 2015a, Wyniki monitoringu siedlisk w roku 2014. Zakres prac realizowanych w 2014 roku oraz wstępne wyniki monitoringu efektów programów rolnośrodowiskowych w zakresie siedlisk [Results of habitat monitoring in 2014. The scope of work carried out in 2014 and preliminary results of monitoring related to agri-environmental programmes and their effects on habitats], Instytut Technologiczno-Przyrodniczy, Falenty, mscr.

Jarzombkowski F., Gutowska E., Kazuń A., Kowalska M., Kotowska D., Kotowska K., Krajewski Ł., Piórkowski H., Szczepaniuk A., Topolska K. \& Żmihorski M., 2015b, Metodyka badań terenowych monitoringu siedlisk przyrodniczych w ramach projektu oceny skuteczności pakietów przyrodniczych programu rolnośrodowiskowego [Fieldwork methods of natural habitat monitoring under the project evaluating the effectiveness of nature packages from the agri-environmental programme], Instytut Technologiczno-Przyrodniczy, Falenty, mscr.

Kamiński J., 2008, Zróżnicowanie florystyczne i walory przyrodnicze łąk 2-kośnych na zagospodarowanym torfowisku w zależności od warunków wilgotnościowych [Floristic diversity and nature conservation values of 2-cut meadows on a managed peat bog in relation to moisture conditions], Woda-Środowisko-Obszary Wiejskie 8, 2a(23): 87-104.

Kondracki J., 2002, Geografia regionalna Polski [Regional geography of Poland], Wydawnictwo Naukowe PWN, Warszawa.

Korzeniak J., 2013, 65XX Eutroficzne łąki wilgotne ze związku Calthion. Wyniki monitoringu w roku 2013 [Eutrophic wet Calthion meadows. Results of moni- toring carried out in 2013], http://siedliska.gios.gov.pl/ [Accessed 19.10.2015].

Kotańska M., 1993, Response of wet meadows of the Calthion alliance to variations of weather and management practices - a thirteen-year study of permanent plots, Studia Naturae 40: 1-48.

Kotowska D. \& Żmihorski M., 2015, Wyniki monitoringu ornitologicznego w 2014 roku. Zakres prac zrealizowanych w 2014 roku oraz wstępne wyniki monitoringu efektów programu rolnośrodowiskowego w zakresie ornitofauny [Results of ornithological monitoring carried out in 2014. The scope of work conducted in 2014 and preliminary results of monitoring related to the agri-environmental programme and their effects on avifauna] Instytut Technologiczno-Przyrodniczy, Falenty.

Kryszak A., 2001, Różnorodność florystyczna łąk i pastwisk klasy Molinio-Arrhenatheretea R. Tx. 1973 w aspekcie ich wartości gospodarczej [Floristic diversity of meadows and grasslands from the class Molinio-Arrhenatheretea R. Tx. 1973 in terms of their economic values], Roczniki AR w Poznaniu, Rozprawy Naukowe 314, Poznań.

Kryszak J., Kryszak A. \& Grynia M., 2005, Zmiany w siedliskach i zbiorowiskach łąkowych w górnym odcinku Baryczy [Changes in habitats and grassland communities in the upper reaches of the Barycz River], Ann. UMCS, sec. E, 60: 41-48.

Kucharski L., 1999, Szata roślinna łąk Polski Środkowej i jej zmiany w XX stuleciu [Grassland vegetation in Central Poland and its transformations in the 20th century], Łódź, Wydaw. Uniw. Łódzkiego, Łódź.

Kurowski J.K. \& Kucharski L., (ed.), 2012, Zagrożone zbiorowiska roślinne, [in:] R. Olaczek (ed.), Czerwona księga roślin województwa łódzkiego [Threatened plant communities [in:] Red book of plants of Łódź Voivodeship], Ogród Botaniczny w Łodzi, Uniwersytet Łódzki, Łódź: 212-269.

Matuszkiewicz W., 2008, Przewodnik do oznaczania zbiorowisk roślinnych Polski [Guide to identification of plant communities of Poland], Wyd. Nauk. PWN, Warszawa.

Mosek B. \& Jargiełło J., 1986, Kierunki sukcesji zbiorowisk roślinnych na łąkach zemborzyckich w latach 1926-1972 [Directions in the succession of Zemborzyce meadow plant communities in 1926-1972], Ann. UMCS, sec. E, 51, 14: 151-161.

Mountford J.O., 1994, Floristic change in English grazing marshes: the impact of 150 years of drainage and landuse change, Watsonia 20: 3-24.

Mróz W., (ed.), 2010, Monitoring siedlisk przyrodniczych. Przewodnik metodyczny, część 1 [Monitoring of natural habitats. Methodological guidebook, Part 1], GIOŚ, Warszawa. 
Nowiński M., 1967, Polskie zbiorowiska trawiaste i turzycowe. Szkic fitosocjologiczny [Polish grassland and sedge communities. Phytosociological draft], PWRiL, Warszawa.

Oświt J., 1991, Roślinność i siedliska zabagnionych dolin rzecznych na tle warunków wodnych [Vegetation and marshy habitats of river valleys in relation to hydrological conditions, Roczn. Nauk Roln., series D, 221: $1-231$.

Pałczyński A., 1975, Bagna Jaćwieskie (pradolina Biebrzy). Zagadnienia geobotaniczne, paleofitosocjologiczne i gospodarcze [Jaćwieskie Wetlands (Biebrza ice-marginal valley). Geobotanical, palaeophytosociological and economic issues], Roczn. Nauk Roln., series $\mathrm{D}, 145$ : 1-322.

Parusel J., Cabała S., Hereźniak J. \& Wika S., (eds), 2012, Czerwona lista zbiorowisk roślinnych województwa śląskiego [Red list of plant communities of Silesia Voivodeship], [in:] J. Parusel (ed.), Czerwone listy zbiorowisk roślinnych, mszaków i porostów województwa śląskiego [Red lists of plant communities, bryophytes and lichenes], Centrum Dziedzictwa Przyrody Górnego Śląska, Katowice: 7-60.

Rosadziński S. \& Brzeg A., 2013, Rzadkie gatunki roślin użytku ekologicznego „Ruskie Stawy” w Kotlinie Zasieckiej na tle lokalnych uwarunkowań siedliskowych [Rare plant species of the ecological site "Ruskie Stawy" in the Zasiek Basin in relation to local habitat conditions], Bad. Fizjogr. 1(B59): 137-151.

Rozporządzenie Ministra Rolnictwa i Rozwoju Wsi z dnia 15 marca 2013 r. w sprawie szczegółowych warunków i trybu przyznawania pomocy finansowej w ramach działania „Program rolnośrodowiskowy” objętego Programem Rozwoju Obszarów Wiejskich na lata 2007-2013 (Dz. U. 2013 poz. 361) [Regulation of the Minister of Agriculture and Rural Development of 15 March 2013 on detailed provisions and procedures for obtaining financial assistance under the "Agri-environmental programme" within the scope of the Rural Development Programme in 2007-2013 (Dz. U. RP [Jour- nal of Laws RP] 2013, item 361)], Kanc. Prezesa Rady Min., Warszawa.

Schrauzer J., Asshoff M. \& Müller F., 1996, Restoration strategies for wet grasslands in Northern Germany, Ecological Engineering 7: 255-278.

Stosik T., 2014, Stan zachowania fitocenoz łąkowych doliny Zwierzynki w Borach Tucholskich [Preservation status of grassland phytocoenoses in Zwierzynka Basin in Tuchola Forest, [in:] T. Stosik, E. Krasicka-Korczyńska, M. Korczyński (eds), Łąki w krajobrazie [Grasslands in the landscape], Polish Botanical Society, Bydgoszcz: $35-48$.

Suder A., 2007, Szata roślinna łąk wilgotnych (Molinietalia caeruleae W. Koch 1926) we wschodniej części Wyżyny Śląskiej [Vegetation cover of wet meadows Molinietalia caeruleae W. Koch 1926 in the eastern part of Silesian Upland], Łąkarstwo w Polsce [Grassland Science in Poland] 10: 159-172.

Tansley A.G., 1946, Introduction to Plant Ecology. A guide for beginners in field study for plant communities, George Allen \& Unwin, London.

Trąba C. \& Wolański P., 2011, Zróżnicowanie florystyczne łąk związków Calthion i Alopecurion w Polsce zagrożenia i ochrona [Floristic diversity of meadows from the alliances Calthion and Alopecurion in Poland - threats and protection.], Woda-Środowisko-Obszary Wiejskie 11, 1 (33): 299-313.

Wójcik T. \& Kotańska M., 2014. Meadow communities with Cirsium canum L. (All.) in the Wielopolska river valley in the Strzyżów Foothills (Western Carpathians), Steciana 18(2): 37-47.

Żmihorski M., 2014, Wyniki monitoringu ornitologicznego w 2013 roku. Zakres prac zrealizowanych w 2013 roku oraz wstępne wyniki monitoringu efektów programu rolnośrodowiskowego $\mathrm{w}$ zakresie ornitofauny [Results of ornithological monitoring in 2013. The scope of work conducted in 2013 and preliminary results of monitoring related to the agri-environmental programme and their effects on avifauna], Instytut Technologiczno-Przyrodniczy, Falenty. 